Bojan Krstic, $\mathrm{PhD}^{1}$

University of Nis, Faculty of Economics

Milos Krstic, $\mathrm{PhD}^{2}$

University of Nis, Faculty of Science and Mathematics
ORIGINAL SCIENTIFIC ARTICLE

Received: February 24, 2015

Accepted: March 14, 2015

\title{
RATIONAL CHOCE THEORY AND RANDOM BEHAVIOUR
}

\begin{abstract}
According to rational choice theory, rational consumers tend to maximize utility under a given budget constraints. This will be achieved if they choose a combination of goods that cannot satisfy their needs and provide the maximum level of utility. Gary Becker imagines irrational consumers who choose bundle on the budget line. As irrational consumers have an equal probability of choosing any bundle on the budget line, on average, we expect that they will pick the bundle lying at the midpoint of the line. The results of research in which artificial Becher's agents choose among more than two commodities rational choice theory is small. And in more than two budget/price situations show that the percentage of agents whose behaviour violate. Adding some factors to Becker's model of random behaviour, experimenters can minimize these minor violations and fit the actor's choice with the theory. In addition, the results of organizations' choices analysis show that the observed agents behave rationally, and this behaviour confirms the theory rational choice. Therefore, rational choice theory is unfalsifiable. As the theory can always fits with the facts, it would have been much more productive if we had admitted that the theory was falsifiable and then debated its explanatory value in specific circumstances.

Key words: rational choice theory, Beker's model of random behaviour, generalized axiom of revealed preference, falsifiability, utility maximization, rationality assumption.
\end{abstract}

JEL classification: A1, D1

\section{ТЕОРИЈА РАЦИОНАЛНОГ ИЗБОРА И СЛУЧАЈНО ПОНАШАҢЕ}

\section{Апстракт}

Према теорији рационалног избора, рацчионални потрошачи врие избор своје потрошье тако да теже да максимизирају корисност на основу датог бучетског ограничења куповине роба. То ће постићи ако изаберу ону комби-

\footnotetext{
${ }^{1}$ bojan.krstic@eknfak.ni.ac.rs

2 krsticmilo3@gmail.com

${ }^{3}$ The paper is the result of the research done as part of the project no. 179066 "Improving the Competitiveness of the Public and Private Sector by Networking Competences in the Process of the European Integrations of Serbia", financed by the Ministry of Education, Science and Technological Development of the Republic of Serbia.
} 
начију добара која може да подмири њихове потребе и обезбеди максималан ниво корисности. Гари Бекер замишља ирачионалне потрошаче како бирају пакет на буцетској линији. Пошто ирационални потрошачи свим пакетима на бучетској криви приписује пођеднаку вероватноћу избора, у просеку, се очекује да одаберу пакет која лежи на средини линије. Резултати истраживања у којима вештачки Бекерови актери бирају између више од две робе и у више од две буцет/иена ситуације показују да је проченат актера, чије понашање не потврђује теорију рационалног избора мали. Укључивањем додатних фактора у Бекеров модел случајног понашања, извођачи истраживаға могу да минимизирају ове минорне виолачије и да избор актера ускладе са теоријом. Поред тога, добијени резултати анализе избора изабраних организација емпиријски показују да се посматрани актери раџионално понашају, чиме се потврђује теорија рационалног избора. Све ово, теорију чини неоповргљивом. Пошто се теорија увек може ускладити са чињеницама, било би много продуктивније признати да је теорија проверљива и онда дебатовати о њеној експланаторној вредности у специфичним околностима.

Кључне речи: теорија рачионалног избора, Бекеров модел случајног понаиања, јак аксиом откривених преференција, оповргљивост, максимизација корисности, претпоставка раџионалности

\section{Introduction}

The notion of rational choice and rational behaviour plays an important role in the methodology of economic science. Content of economic science consists of descriptions human behaviour and by the notion of human behaviour is included not only individual behaviour, but also the random consequences from the mutual contact of individuals, as well as the effects of different institutional arrangements. In the paper entitled "Economic Approach to Human Behaviour", Becker (2003) stresses that: "economic theory, as a scientific discipline, differs from the other fields of social knowledge in its approach. On the whole, the essence of the economic approach is comprised from the merged assumptions of maximizing behaviour, market balance, preference stability" (p. 28).

The author of the contemporary definition of the subject of economics, Robbins (1993) stressed that: "economics is a science which studies human behaviour based on the relationships between the aims and the limited means suitable for alternative uses" (p. 19). This leads to the conclusion that, as a science, economics does not study the nature of certain forms of human behaviour, but views and analyses them from the aspect of the comprehensiveness of (all) social links and their inclusion in social structures (Valeryevich, 1997).

In order to explain individual behaviour, economic science uses the rational choice model. The main assumption in the rational choice model is that the behaviour of all economic actors is perfectly rational. The perfect form of rationality is based on the principle of maximization which states the following: the consumer always tends to maximize utility, while the manufacturer tends to maximize profit. 
In addition, the rational choice model includes and combines in itself the following propositions:

1. An actor finds himself in a situation in which the quantity of the available resources is limited. For this reason, he cannot satisfy all his own needs and thus must make a choice.

2. The factors which condition this choice are divided into two groups: preferences and constraints. Preferences have the character of the subjective needs of an individual, while constraints represent factors that reduce the ability (skills) of the individual and decrease one's potential for innovation.

3. In making his selection, the economic man is driven by his own tendencies, not the interests of his business partner, and not by the adopted social norms traditions etc.

4. Actors' choice is rational if he chooses option which will provide maximum utility (Hafner \& Krstic, 2014).

The aim of the paper is to find whether organizations act rationally, on the basis of collected data about organizations' choice. The results of research empirically show that these subjects behave rationally, and thus rational choice theory is conformed. In the paper, we implemented the results of research, that show behaviour is inconsistent with the rational choice model, in order to explain how can behaviour of individuals fit with the rational choice theory by ad hoc introducing the additional hypothesis.

\section{Rational choice theory}

Rational behaviour of individuals is associated with the principle of methodological individualism, according to which all social phenomena can be expressed in the terms of individual action. "Social reality, expressed by cultural values and norms, is the result of previous actions" (Štulhover, 1995, p. 174). In this way, rational choice theory interprets the world as a strategic space of the maximization of individual interests. Social behaviour is primarily rational (emotion is a residual factor), and actors consciously tend to realize their maximum usefulness in an environment that is characterized by limited resources. The choice of the actors' goals depends on their preferences.

Rational choice theorists observe economic actors as individuals who are able to "identify all possible alternatives, paths of action, constrains and to select the optimum alternative" (Golubovic, 2011, p. 166). The choice of alternative is determined by the amount of the collected information. For the model of rational choice, it is assumed that the actors have the optimum amount of information. However, real people do not have all the necessary information, or the information is insufficiently precise and/or unreliable.

Limitations of the model of rational choice caused the emergence of an approach in which the model of rational choice is expanded and explained. In one of them, the stochastic model is applied. In the stochastic model, a selection is made between the number of "lottery tickets", each of which will promise to bring the amounts $m_{1}, m_{2}$ etc. with probabilities $p_{1}$, $p_{2}$ etc. "Lottery Ticket" is the paradigm of the actor's choice, where the outcome of the proceedings is not known with certainty, but in which the participant calculates the probability of various possible outcomes based on his experience and intuition (Boricic, 2005). 
The second (another, alternative) approach compares the rational choice model with a model of random behaviour. According to this approach, the behaviour of an individual is random and only if he picks an alternative in his choice set according to some probability distribution on the set, typically a uniform distribution where each alternative in the set has an equal probability of being selected. The point of comparing rational choice with random behaviour is that the latter seems to lack the characteristics of rationality and thus it diverges from rational choice more significantly than from other models of behaviour.

\section{Random behaviour from Gary Becker to experiments on demand}

This section is about the evolution of the interpretation and the use of Becker's model from Becker's original 1962 article to the modern experimental literature on an individual demand. Special attention is paid to (on) the analysis of the relationship between rational choice theory and Becker's model of random behaviour.

\subsection{Becker's expected random choice}

In his model of random behaviour, Gari Becker presents a random consumer as someone who chooses a bundle on the budget line according to the uniform distribution of probability, and compares the implications of random behaviour with the implication of rational choice theory. A random consumer has an equal probability to choose all the bundles on the budget line. On average, we expect them to pick the point that lies in the middle of the budget line and thus spend equal amounts of money on both products (Figure 1).

Suppose that an observed irrational consumer has two types of goods available: $x$ and $y$, and the price of goods $y$ is reduced. Reducing the price of goods $y$ will shift the budget constraint to the right. With the budget constraint shift to the right, the slope of the curve (budget constraints) is changed. As the price of goods $y$ is reducing, and the price of goods $x$ remains the same, the consumer can replace one unit of goods $x$ for several units of goods $y$. Accordingly, the new budget line (CD) that passes through $e_{0}$ is steeper than $\mathrm{AB}$. With the given shift budget constraints and preferences of the consumers, the consumer's (new) expected optimum shifts from $e_{0}$ point to point $e_{1}$.

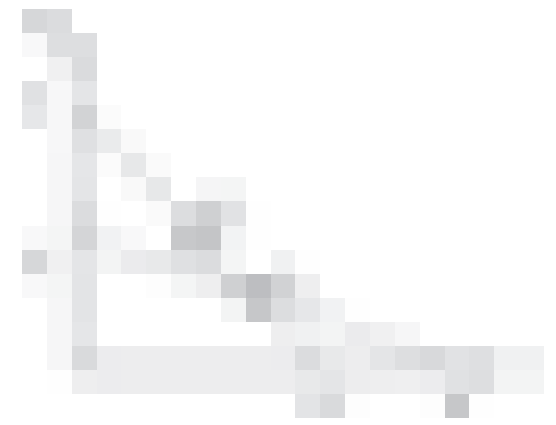

Figure 1: Random choice and substitution effect

Source: Moscatia. I., \& Tubaro, P. (2011.) Becker random behavior and the as-if defense of rational choice theory in demand analysis. Journal of Economic Methodology, 108(2), 110. 
According to rational choice theory, the market of rational and mutually independent actors will form a negatively sloped demand curve. The same is true for Becker's model of random behaviour. The larger number of the random consumers in the market, the more likely it is that the unexpected behaviour of consumers will not determine the average market demand, and thus the average market demand will be equal as the individual expected demand. Hence, a market with a large number of random and mutually independent actors will form almost a negatively sloped demand curve, at least on average.

\subsection{The limitations of Becker's result}

Becker's view that both rational and random consumers have a negatively sloped demand curve is based on the assumption that the random choice can be identified with the outcome of random behaviour. It should be emphasized that the random consumer does not always choose the combination of goods lying at the middle of the budget line. In effect, when random choice is reduced to the expected outcome, a random consumer cannot be distinguished from a rational consumer with a Cobb-Douglas utility function, because both of them pick the combination of goods that lies at the middle of the budget line.

When we consider each and every random choice, and rule out the irrational consumers who are totally indifferent between alternatives and thus rational in picking one at random, the convergence between rational and random behaviour evaporates (Moscatia \& Tubaro, 2011). Random behaviour no longer implies a negative substitution effect. The compensated budget line CD in Figure 1 shows that there is a probability which equals the ratio between the length of segments $e_{0} \mathrm{D}$ and $\mathrm{CD}$ that the random consumer chooses a bundle to the right of $e_{0}$. Therefore, Becker's model of random behaviour describes the probability that the irrational consumer displays a positive substitution effect which rational choice theory does not explain.

\subsection{Random behaviour in experiments on individual demand}

In experiments on individual demand, prices of bundles are known variables. The participants know their propensity to consume and are able to rank their needs. Having in mind the budget constraint and the intention to accomplish maximum utility, consumers make a choice and form their own demand for goods. The experimenter notes subjects' choices and checks whether they satisfy the Generalized Axiom of Revealed Preference (GARP). According to GARP, "if the subject reveals a preference for bundle $e_{0}$ over bundle $e_{1}$, that is, if she chooses $e_{0}$ when $e_{1}$ is available and costs no more than $e_{0}$, and if she subsequently and directly reveals that she prefers $e_{1}$ to $e_{2}, e_{2}$ to $e_{3}, \ldots$, and $e_{n-1}$ to $e_{n}$, then the subject cannot choose $e_{n}$ when $e_{0}$ is available and costs strictly less than $e_{n}$ " (Moscati \& Tubaro, 2011, p. 112). The Generalized Axiom of Revealed Preference is a logical implication of rational choice theory in the sense that the choices of a subject could be seen as if they were generated by the maximization of a locally non-satiated utility function if, and only if, they satisfy GARP (Lipton, 2004).

Figure (2a-e) shows a rough geometrical prediction when choices satisfy GARP and when they violate it. In figure 2 , the two budget/price situations are represented by the budget lines. The first situation is illustrated by budget line $\mathrm{AB}$. The second situation 
is presented (illustrated) by budget line CD. The choices represented in Figure $(2 \mathrm{a}-\mathrm{c}, \mathrm{e})$ satisfy GARP, while the choices in Figure 2 (d) violate it. In situation $A B$, the participant reveals that he prefers $e_{0}$ to $e_{1}$, but in situation $\mathrm{CD}$, he chooses $e_{1}$, although $e_{0} \operatorname{costs}$ strictly less than $e_{1}$ (Figure 2 (d)). In Figure 2 (e) the two-budget/price situations coincide, but the subject chooses $e_{0}$ in $\mathrm{AB}$ and $e_{1}$ in $\mathrm{CD}$. This choice does not violate GARP, since neither of the two bundles costs strictly less than the other.

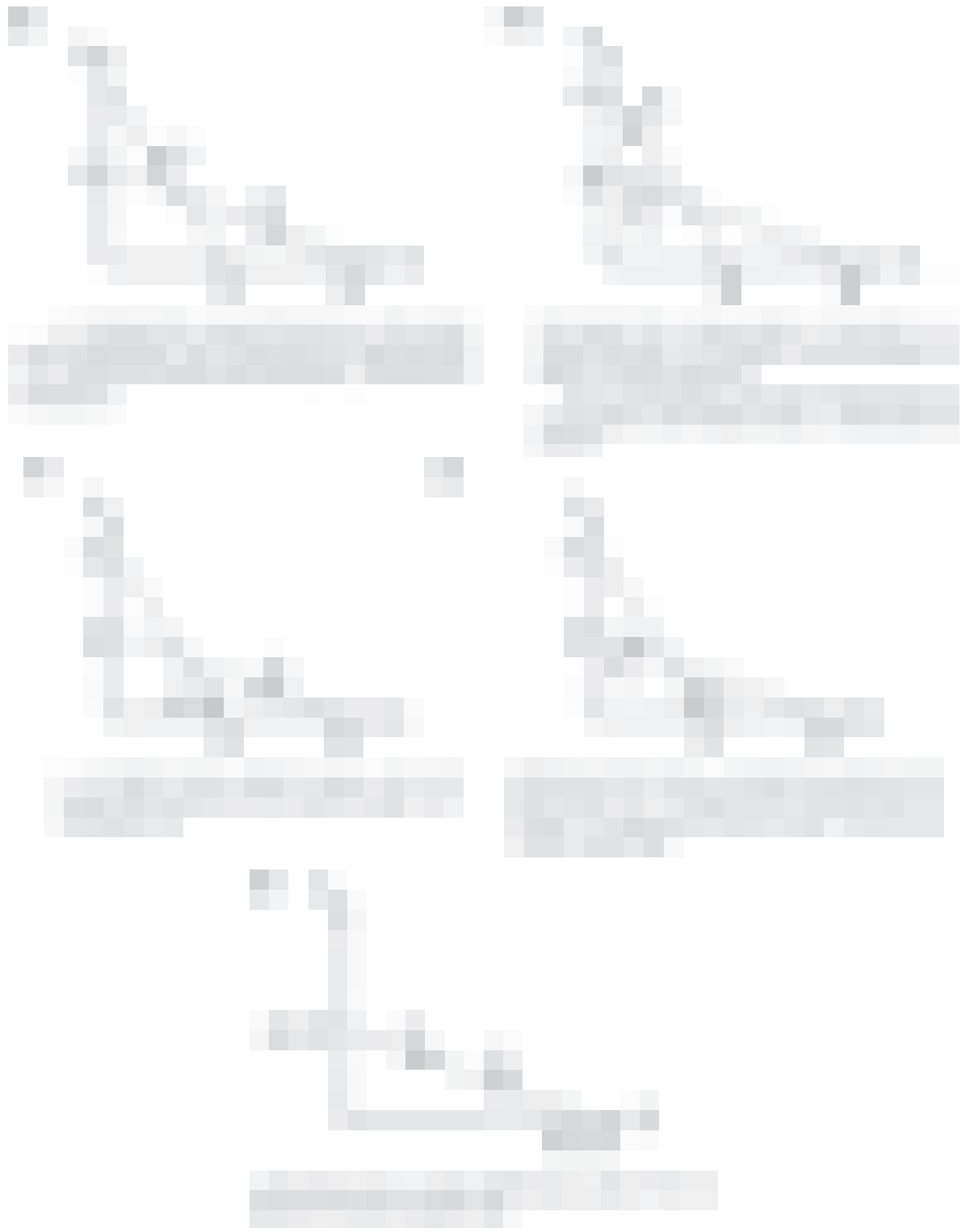

Figure 2: When choices satisfy GARP and when they violate it.

Source: Moscatia. I., Tubaro, P. (2011). Becker random behavior and the as-if defense of rational choice theory in demand analysis. Journal of Economic Methodology, 108(2), 112. 
However, there are two problems regarding GARP as a test for testing the results of rational choice theory, and confirming or rejecting their justification. Firstly, in order to determine the number of GARP violations in an experiment, we need to define the criterion for demarcation between the choices within and outside the experiment. Experimental studies usually traverse the problem by assuming that the criterion of separability (the criterion for demarcation) is more or less known. Secondly, even if all choices made in the experiment are in accordance with the GARP, this result can be interpreted as an inadequate support of RCT. Indeed, many real participants satisfy GARP. "GARP violations become unlikely when the budget hyperplanes intersect near the axes, and impossible when they intersect on the axes or do not intersect at all" (Moscati \& Tubaro, 2011, p. 113).

In statistical terms, one of the essential questions is evaluating the power of a test, that is, the probability of a test to reject the null hypothesis (in our case, rational choice theory) when the rational choice theory is false. To assess the power of GARP as a test, it is necessary to formulate the hypothesis about the decision rule that could have generated choices. It is important to point out that, in modern economic literature, Becker's model of random behaviour is used as the hypothesis for testing the power of GARP. The aim is to increase the probability of GARP violations by introducing a Becker's model. "In this case, even if RCT is false and human subjects choose at random, they would rarely violate GARP” (Moscati \& Tubaro, 2011, p. 113).

To calculate the probability of GARP violations, it is necessary to overcome another obstacle. It is very difficult to calculate the a priori probability of GARP violations when random consumers choose among more than two commodities and in more than two budget/price situations. To traverse this problem, experimenters use Monte Carlo methods to create a population of artificial Becker participants who face the same budget/price situations that the real participants were faced with in the experiment. In each situation, a participant (Becker's participant) chooses a bundle on the budget line according to the uniform distribution of probability. "His choices over the entire set of budget/price situations may or may not violate GARP" (Moscati \& Tubaro, 2011, p. 113). If the percentage of random respondents that violate GARP is small, then the fact that people rarely violate GARP represents little support for rational choice theory, since GARP violations rarely occur due to the objective difficulty of violating GARP under the budget/price combinations of the experiment, but appear due to the rational behaviour of the represents.

The small-scale of GARP violations presents the following problem. In all experiments, choices of certain participants violate GARP. This merely confirms that there are experimental data falsifying rational choice theory. "However, in many cases, GARP violations are rare, in the sense that nearly all subjects satisfied GARP, and not severe, in the sense that the violators were 'close' to pass GARP" (Moscatia \& Tubaro, 2011, p. 113). However, it can be discussed whether it is really appropriate to fully reject the rational choice theory? By including exogenous factors in the model, as in the case of the stochastic extension of rational choice theory, a'la Fechner would be able to rationalize these minor GARP violations.

Relying on the work of Sidney Afriat (Sydney Afriat), Professor at the Department of Economic Policy, University of Siena, Hal Varian found the Weak Axiom of Revealed Preference, which he called GARP (e). The Weak Axiom of Revealed Preference reflects 
the degree of violations through parameters $e$, and is called GARP (e) (Varian, 1998). The index measures the extent to which the budget constraints should be modified to accommodate for the observed GARP violations.

In order to determine how the reduction of the budget influences choices, we show the situations in which the choices violate GARP. When the budget is reduced in the way that the compensated budget line C'D' passes through $e_{0}$, then $e_{0}$ and $e_{1}$ do not violate GARP (Figure 4). The ratio between income C'D' and income CD expresses the income reduction needed to let GARP violations disappear, and can be interpreted as an indicator of the money the subject wastes by not choosing rationally.

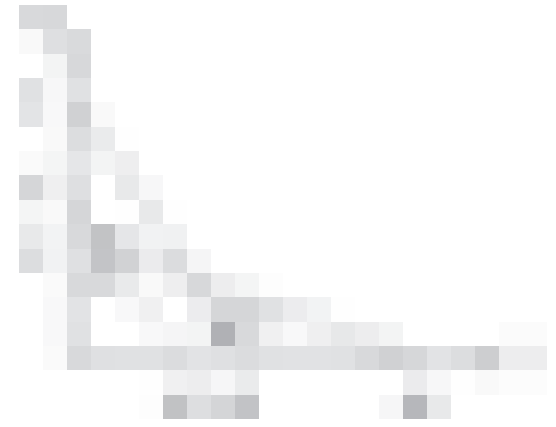

Figure 3: GARP (e).

Source: Moscatia. I., Tubaro, P. (2011). Becker random behavior and the as-if defense of rational choice theory in demand analysis. Journal of Economic Methodology, 108(2), 114

\section{Empirical analysis of observed organizations' choice}

Rational choice theory is based on methodological individualism. "The basis of methodological individualism is the idea that the properties of the system are judged on the basis of the properties of its elements" (Kitanovic, Golubovic \& Petrovic, 2009, p. 40). Methodological individualism does not deny the existence of complex social phenomena, such as organizations. These phenomena are a social reality, but according to the supporters of this philosophical school, societies exist only as epiphenomena that emerge from people's minds.

The representatives of this philosophical school see the organization as theoretically postulated subjects trying to accomplish the optimum value of the goal function. Depending on the nature of the problem, the optimum will be considered the maximum or minimal value (the goal function). In the domain of consumption, the goal function of participants (individuals, organizations, etc.) is related to maximizing utility. If we have a list of goods bought by an organization when faced with different prices, we can apply the strong axiom of revealed preferences in order to determine whether the observed organizations choose the combination of goods which realizes the optimum (maximum) value of the goal function.

We have chosen three organizations (Health Center, Faculty of Economics and Faculty of Sciences and Mathematics, University of Nis) and defined the hypothesis according to which the observed organizations accomplish the optimum (maximum) 
value of the goal function. The subject of the analysis represents a combination of goods that the organizations buy at different prices. The following goods were used for the analysis of the observed organizations ' choice:

1. Health Center: gloves, surgical rubbers, systems for infusion and needles (Table 1).

2. Faculty of Economics: copy paper, writing paper with a rectangular pattern, envelopes and marker (Table 2).

3. Faculty of Sciences and Mathematics: paper printing paper, marker, envelopes and folder (Table 3)

Table 1: The consumption of the Health Centre in Niš.

\begin{tabular}{|c|c|c|c|c|c|c|c|c|}
\hline Observations & $p_{1}$ & $p_{2}$ & $p_{3}$ & $p_{4}$ & $x_{1}$ & $x_{2}$ & $x_{3}$ & $x_{4}$ \\
\hline 1 & 2.06 & 9.5 & 3.7 & 2.5 & 500000 & 42000 & 1500 & 250000 \\
\hline 2 & 3.07 & 12.59 & 3.38 & 2.5 & 500000 & 40000 & 1008 & 500000 \\
\hline 3 & 5.2 & 16.4 & 3.5 & 1.55 & 456000 & 42200 & 1200 & 300000 \\
\hline 4 & 5.2 & 16.4 & 3.5 & 1.55 & 456000 & 42200 & 1200 & 300000 \\
\hline
\end{tabular}

Source: Procurement Department of the Health Centre.

Table 2: The consumption of Faculty of Economics in Niš.

\begin{tabular}{|c|c|c|c|c|c|c|c|c|}
\hline Observations & $p_{1}$ & $p_{2}$ & $p_{3}$ & $p_{4}$ & $x_{1}$ & $x_{2}$ & $x_{3}$ & $x_{4}$ \\
\hline 1 & 268.93 & 417.60 & 2.58 & 6.13 & 200 & 1 & 200 & 100 \\
\hline 2 & 326.40 & 394.50 & 3.00 & 18.00 & 50 & 3 & 150 & 200 \\
\hline 3 & 326.4 & 405.7 & 4.65 & 17.82 & 50 & 2 & 200 & 100 \\
\hline 4 & 326.40 & 298.6 & 4.65 & 18.82 & 100 & 5 & 250 & 150 \\
\hline
\end{tabular}

Source: The Accounting of Faculty of Economics.

Table 3: The consumption of Faculty of Sciences and Mathematics.

\begin{tabular}{|c|c|c|c|c|c|c|c|c|}
\hline Observations & $p_{1}$ & $p_{2}$ & $p_{3}$ & $p_{4}$ & $x_{1}$ & $x_{2}$ & $x_{3}$ & $x_{4}$ \\
\hline 1 & 282.55 & 20 & 10 & 2.15 & 200 & 50 & 1000 & 2000 \\
\hline 2 & 262.47 & 18 & 8 & 3.15 & 400 & 30 & 1500 & 1500 \\
\hline 3 & 247.86 & 15 & 8 & 1.85 & 420 & 40 & 2000 & 1800 \\
\hline 4 & 312.26 & 25 & 7 & 2 & 180 & 20 & 3000 & 2000 \\
\hline
\end{tabular}

Source: The Accounting of Faculty of Sciences and Mathematics.

Table 5: Price of each bundle in each set price - the case of Health Center Bundles

\begin{tabular}{|c|c|c|c|c|}
\hline & 1 & 2 & 3 & 4 \\
\hline \multirow{4}{*}{ Prices } & 2059550 & 2663730 & 2094700 & 2094700 \\
\hline & 2693850* & 3292007 & 2685274* & 2685274* \\
\hline & 3681550 & 4034528 & 3532480 & 3532480 \\
\hline & 3681550 & 4034528 & 3532480 & 3532480 \\
\hline
\end{tabular}

On the basis of data from Table 1, we can calculate how much the Health Center pays when it buys each bundle for each different set price. For example, the data in Table 5 (third row, first column), shows how much money this health organizations must spend in the third set of the price in order to buy the first combination of goods.

The diagonal data in Table 5 show how much the organization spends for each choice. The data in the row are used to determine how much money the Health Center 
spends to buy a different combination of goods. By comparing the data in Table 5, it can be seen whether, say, the Health Center prefers bundle 2 to bundle 1, and we find whether the data in row 2, column 1 (how much money the organization needs to spend in the second set price to buy the first combination of goods) is less than the data in row 2 , column 2 (how much money the organization spent in the second set price to buy the second combination of goods). In this case, the bundle was available when the Health Center bought bundle 2, which means that bundle 2 is revealed to be preferred to bundle 1. Therefore, in Table 5, we put a star in row 2, column 1 , and the data in row s, column $t$, only if the number in this field is smaller than the number in row $s$.

This table can be used to determine the violation of GARP, which is violated only if the stars lie in row $s$, column $t$, and in row $s$, column $t$ (Varian, 2014). Since Table 5 shows no situation where the stars lie in row $t$, column $s$, and in row $s$, column $t$, we know that the observations are in line with rational choice theory. They were reached by the optimizing entity that always chooses the best things they can afford.

\section{Limitations of rational choice theory}

The results of the analysis of the behaviour of selected organizations show that rational choice theory is true. Defending his academic position from the "economic imperialism" of rational choice theory, many scientists have attempted falsification, claiming that the utility maximization assumption and the rationality assumption are not "grounded" in objective reality. Such defense attempts against the invasion of rational choice theory are methodologically flawed for the following reasons.

Firstly, the utility maximization assumption is not falsifiable. Writing about utility maximization, Samuelson (1937) stressed, "all types of observable behaviour might conceivably result from such an assumption" (p. 156). Since the utility cannot be objectively observed, all kinds of behaviour can be explained in terms of the idea, without fear of refutation. Sidney Winter and Lawrence Boland also emphasize that no evidence can refute the theory that agents are maximizing some hidden or unknown variable such as utility (Winter, 1964).

The second reason for the inability to empirically test rational choice theory is reflected in the fact that the results of the participants' choices can always fit the utility maximization assumption and rational choice theory. In all researches (Hodgson, 2012), the choices of certain participants violate GARP. This only shows that there are experimental data that falsify rational choice theory. By including additional factors in the model, experimenters could rationalize these minor GARP violations and coordinate the participants' choices with rational choice theory.

If experiments show that a certain percentage of respondents choose the option with a lower expected value, the experimenters can always provide evidence that is consistent with the utility maximization assumption by introducing additional variables. Assume that a respondent is faced with a choice between $\$ 10$ with certainty, and $\$ 1,000$ with a probability of 2 per cent. The results of the experiment indicate that there are respondents who choose the option of $\$ 10$, despite the fact that the expected value of the second option is higher (Slovic \& Lichtenstein, 1983). These results do not falsify rational choice theory, once we accept that the expected utility is not necessarily measured 
in terms of the monetary payoffs. If we assume an added disutility associated with a risky and low probability choice, then the rational choice theory that indicates that people are maximizing their utility is not falsified by this experiment. "A risk-averse participant may not maximize expected monetary value, but may still be maximizing expected utility. With appropriate manipulation, the choice of $\$ 10$ can be made to be perfectly consistent with the maximization of the expected utility, instead of the maximization of the expected monetary value of the payoff' (Hodgson, 2013, p. 97).

The idea that the utility maximization cannot be observed in real life was confirmed by the results of the following research. The results of the experiment clearly indicate that most respondents prefer option $A$ with an expected value of $\$ 4$ to option $B$ with an expected value of $\$ 5$. Since most respondents prefer option $A$ with an expected value of $\$ 4$ to option $B$ with an expected value of $\$ 5$, then it can be assumed that "there are additional attributes of option $A$ (for example, we may enjoy losing or gaining pleasure from seeing others win) that are consistent with the view that it yields higher overall expected utility for the subject" (Hodgson, 2012, p. 97). Since we can never show that some variables that cannot be directly observed (such as utility) do not maximize, then rational choice theory is resistant to every empirical "impact".

The key problem with the rationality assumption is that it is so general that it can explain everything. Consequently, the explanatory power of rational choice theory is significantly reduced in specific cases. For example, rational choice theory cannot explain the positive substitution effect or probability that the consumer chooses a point below budget line CD that is located to the right of $e_{0}$ (Figure 1). Each point below the budget line is suboptimal. If the consumer chooses these points, then his behaviour is irrational. However, in his article, entitled "Irrational Behaviour and Economic Theory", Becker shows how the choice of individuals who do not behave rationally leads to economic outcomes "as if" they behave rationally (Becker, 1962). When alcohol prices increase, an alcoholic reduces the consumption of alcohol. This is due to the income effect or budget constraint that exists regardless of whether someone is drunk or not. In this case, the reduction is not the result of rational behaviour or the substitution of the consumption of alcohol with something else.

\section{Conclusion}

As critics question the validity rational choice theory with the unfounded claim that its basic postulates are falsified, the proponents erroneously claim that they have been rigorously confirmed. In his papers, Hirshleifer (1985) shows that: "we must reject rational choice theory to the extent that it violates the evidence about human behavior" (p. 59). However, this view is due to a methodological misunderstanding. No evidence can refute rational choice theory. There is no evidence that does not fit into any version of the theory of rationality. The experimental evidence about ranking preferences and cognitive 'anomalies' forms a new and empirically compatible theory, but it does not, in principle, refute the old version based on rational choice.

Certain authors, such as Eichner, have based their criticism on "an untenable and empiricist view of science that denies that non-falsifiable and 'metaphysical' assumptions are essential to any science" (Hodgson, 2012, p. 102). In fact, all sciences depend upon the propositions that cannot be tested. No theory can be composed entirely of empirically 
confirmed elements. The concepts, which are previously created, make sense of the fact. All concepts cannot be empirically tested. Any 'test' relies on prior concepts or categories. As a result, all sciences extensively use some untestable and metaphysical assumptions. For this reason, the empiricist criticism of rational choice theory is untenable. In practice, the denial of the essential role of non-falsifiable assumptions in theory disables the independent elaboration of theoretical constructions. Since it is practically impossible to test all assumptions, any theoretical construction cannot be empirically tested.

\section{References}

Becker, G. (1962). Irrational Behaviour and Economic Theory. Journal of Political Economy, 70(1). 1-13.

Беккер, Г. (2003). Человеческое поведение: экономический подход. М.: Изд-во: ГУ ВШЭ.

Boricic, B. (2005). Kenneth J. Arrow. Ekonomski anali, 50(165), 225-234.

Eichner, S.A. (1983) Why Economics is Not Yet a Science, New York, Sharpe.

Golubovic, N. (2011). Društvena ekonomika. Ekonomski fakultet. Niš.

Gintis, H. (2009). The Bounds of Reason: Game Theory and the Unification of the Behavioural Sciences. Princeton University Press. Princeton.

Hodgson, G. (2013). On the Limits of Rational Choice Theory. Economic Thought, 1(1), 94-108.

Hirshleifer, J. (1985). The Expanding Domain of Economics. American Economic Review, 75(6), 53-68.

Kitanovic, D., Golubovic, N., \& Petrovic, D. (2009). Osnovi ekonomije. Ekonomski fakultet. Niš.

Hafner, P., Krstic M. (2014). Rational economic behavior - interdisciplinary approach. Ekonomika, 60(4): 155-164.

Лайонел, Р. (1993). Предмет экономической науки. THESIS, 1, 10-23.

Lipton, P. (2004). Inference to the Best Explanation. Routledge. London.

Moscatia, I., \& Tubaro, P. (2011). Becker random behaviour and the as-if defense of rational choice theory in demand analysis. Journal of Economic Methodology, 108(2), 107-128.

Miroljub, L. (2003). Osnovi ekonomije. Stubovi kulture. Beograd.

Радаев, В. (1997). Экономическая социология (к определению предмета). Общественные науки и современность, 3, 106-113.

Samuelson, P. (1937). A Note on the Measurement of Utility. Review of Economic Studies, 4(2), 155-161.

Slovic, P., \& Lichtenstein, S. (1983). Preference Reversals: A Broader Perspective. American Economic Review, 73(4), 596-605.

Štulhofer, A. (1995). Etnicitet i racionalni izbora: od identifikacije do kolektivne akcije. Studia ethnologica Croatica, 174(1), 173-182. 
Varijan, H. (2014). Mikroekonomija. Centar za izdavačku delatnost. Beograd.

Varian, H. (1988). Revealed Preference with a Subset of Goods. Journal of Economic Theory, 46, 179-185.

Winter, S. (1964). Economic "Natural Selection" and the Theory of the Firm. Yale Economic Essays, 4(1), 225-272. 